INTERNATIONAL JOURNAL OF SYSTEMATIC BACTERIOLOGY

Vol. 20, No. 3 July 1970

pp. $249-254$

Copyright 1970, Iowa State University Press

\title{
PRESENT STATUS OF THE SPECIES MICROCOCCUS FREUDENREICHII GUILLEBEAU 1891
}

Tom Bergan, Kjell Bфvre and Berit Hovig

Kaptein W. Wilhelmsen og Frues Bakteriologiske Institutt Rikshospitalet, University of Oslo, Oslo, Norway

\begin{abstract}
The results of a search for a neotype strain of $\mathrm{Micrococcus}$ freudenreichii Guillebeau 1891 indicate (1) either that the strainCCM 764 should be designated as neotype strain of $M$. freudenreichii and that this species be defined accordingly, or (2) that the name M. freudenreichii should be placed in the list of nomina rejicienda as a nomen dubium. It is recommended that the Subcommitte on Taxonomy of Staphylococci and Micrococci of the International Committee on Nomenclature of Bacteria be invited to evaluate the situation and subsequently initiate any action that may seem necessary in relation to the Judicial Commission.
\end{abstract}

In 1891, Guillebeau described a Gram-positive coccus which he isolated from ropy milk and named Micrococcus freudenreichii. The organism was characterized as having (I) completely sphaerical cocci of $2 \mu$ diameter, (2) yellow to brownish pigment, (3) mucoid colonies, (4) gelatin liquefaction and (5) production of ropy milk. No type strain was designated and no holotype is in existence. Consequently, a search for a suitable neotype strain has been carried out, with the result reported below.

In a previous study (Bergan et a1. 1970a) it became clear that the name $M$. freudenreichii has be en attached to various biotypes. The conclusion of that study was that the strain ATCC 407 and its substrain CCM 764 were the closest to the original description. This biotype corres ponded well with the circumscription given in the Bergey's Manual ever since its first edition in 1923. It also reflects the definition given in Krasil'nikov (1949). The strain ATCC 407 has been employed as reference strain for the species in several recent publications (Auletta and Kennedy 1966; Evans et al. 1955; Thatcher and Simon 1957). Consequently, it is certain that ATCC 407 and CCM 764 represent the biotype commonly accepted today as $\mathrm{M}$. freudenreichii. The base composition of this strain is within the range presently compatible with the genus Micrococcus (Bergan et al. 1970b; Boháček and Kocur 1970) and has been determined by thermal denaturation to be $59 \% \mathrm{G}+\mathrm{C}$ (Auletta and Kennedy 1966) and by $\mathrm{CsCl}$ density gradient determination to be $58 \% \mathrm{G}+\mathrm{C}$ (Bergan et al. 1970a).

It is possible, however, that we are dealing with a type of circular identification of the strain ATCC 407 (= CCM 764) as M. freudenreichii, since it is likely that the description in Bergey's Manual was based on this very biotype. The strain was isolated from milk by Hucker, who 
deposited it with the American Type Culture Collection. Hucker, however, also acted as a consultant to the editors of the first edition of the Manual. He was just completing a large study on the classification of species within the genus Micrococcus and gave the following characterization (Hucker 1924):

"Micrococcus freudenreichii Guille beau 1899 [sic!]

Facultative parasite. Liquefies gelatin. Does not reduce nitrates. Variable in acid production from dextrose, lactose, and sucrose. Generally does not ferment mannite or glycerin. Gram variable. Generally does not produce sufficient acid to curdle milk. Cells occur singly or in clumps. Can utilize ammonium salts as an only source of nitrogen."

It 'will be noted that the Guillebeau characteristics of ropy milk production and mucoid colony appearance were not mentioned by Hucker. Likewise, no mention has been made of these traits in the seven editions of Bergey's Manual (1923-1957).

The strains ATCC 407 and CCM 764 do have brownish pigment, although this takes several days to develop; they appear as white colonies at first. The strains do have capsules as demonstrable by a capsular stain (Bergan et al. 1970a), but are not overtly mucoid, although the colonies may "melt" together in the fashion of mucoid colonies.

It is pertinent to note that the orthography in the original paper by Guillebeau (1891) was Micrococcus freudenreichi. According to Recommendation 27 of the International Code of Nomenclature (1966), an epithet derived from a personal noun ending with a consonant should terminate with -ii. This form was correctly substituted by Migula (1900) and has been used since (Auletta and Kennedy 1966; Bergey's Manual 1923, 1957; Winslow and Winslow 1908). The Migula description did not add any characteristics to the description although it seems that he personally studied an authentic strain.

The circumstance that ATCC 407 or CCM 764 did not fit all the characteristics of Guillebeau's description prompted us to search world-wide sources for representative strains of this species. All culture collections mentioned in the footnote* have been approached, including the WHO International Center for Information and Distribution of Type Cultures, Lausanne, Switzerland.

\footnotetext{
* American Type Culture Collection; Rockville, Md., USA (ATCC); Czechoslovak Collectión of Microorganisms, Brno, Czechoslovakia (CCM); Collection de 1'Institut Pasteur, Paris, France; Central Institute of Plant Production, Prágua-Ruzyne, Czechoslovakia (CRIPP); Dairy Research Institute, Palmerston, New Zealand (DRI); Department of Type Cultures, Institute for Microbiology, USSR Academy of Sciences, Moscow, USSR; Institute for Fermentation, Osaka, Japan (IFO); Microbiology Section, Laboratories of Food and Drug Directorate, Department of Health and Welfare, Ottawa, Canada; Ontario Agricultural College, Guelph, Canada (OAC); National Communicable Disease Center, Atlanta, Ga., USA; National Collection of Dairy Organisms, Reading, England (NCDO); National Collection of Industrial Bacteria, Aberdeen, Scotland (NCIB); National Collection of Industrial Microorganisms, Poony, India.
} 
This has resulted in the following strains with the designation $\mathrm{M}$. freudenreichii:

ATCC 407
CCM 764
CRIPP A6
CRIPP A171
DRI 1223 ( = NCDO 1 233)
IFO 3778 (= ATCC 8459)

\author{
IFO 13006 \\ OAC 268 (former ATCC 325) \\ NCDO 1222 \\ NCDO 1223 \\ NCIB 2699 (= ATCC 8459)
}

The characteristics of the first four strains and the last one are reported in detail by Bergan et al. (1970a). Some properties of the remainder are recorded in Table 1 .

Strains CRIPP A6, CRIPP A171, NCDO 1222, NCDO 1223, OAC 268, and DRI 1223 are typical coagulase negative white staphylococci by both colonial characteristics and biochemical properties. The substrains of ATCC 8459, NCIB 2699 and IFO 3778 were identical and are not classifiable as micrococci or staphylococci (Bergan et al. 1970a). The strain IFO 13006 turned out to be a short Gram-negative rod. None of the strains received were mucoid, pigmented, or produced ropy milk. Thus, left on the list of possible M. freudenreichii remained only ATCC 407 and its substrain CCM 764.

Consequently, it is difficult to find a strain which complies completely with the few characteristics given in Guillebeau's original description of M. freudenreichii. It is possible that the microbe studied by him today is allotted to another species or would be considered merely a variant of a recognized species.

Accordingly, we have considered the relationship of mucoid strains of Staphylococcus aureus to Guillebeau's M. freudenreichii. One such strain has been described by Henriksen $(19 \overline{48)}$. This was coagulase positive and liquefied gelatin. It coagulated milk within 14 days, but its ability to produce ropy milk is unknown.

Another mucoid strain of S. aureus, CCM 2286, was subjected to careful consideration, $\mathrm{cfr}$. Table l. Its size is of the same order as the original $\mathrm{M}$. freudenreichii, and it is mucoid and liquefies gelatin. Its pigmentation is in accordance with the first description (Guillebeau 1891):

"Die Kulturen sind stets gelb, manchmal rein schwefelgelb,

Manchmal schmutzig gelblich braun."

In milk, it increased viscosity more than ATCC 407, CCM 764, or M. mucilaginosus (Migula 1900; Bergan et al. 1970a), but not to the extent apparently observed by Guillebeau:

"... wird in kurzer Zeit so stark fadenziehend, dass man mit dem Platindrahte dünnste Fäden von $\frac{1}{2}-1 \mathrm{~m}$. Länge ausziehen kann, ja aus älteren Kulturen können etwas dichtere Fäden von vielen Metern Länge erhalten werden."

In his treatise, Guillebeau paid much attention to the production of ropy milk by $M$. freudenreichii. It appears, however, that this property has been lost in other species, e.g. , Alcaligenes viscolactis (S. viscosus) NCIB 494 (Sandvik 1969). Although ropy milk production would have been of considerable value if present, it is probably not a prerequisite for the designation $M$. freudenreichii in the strains ATCC 407, CCM 764, or CCM 2286. 
Table 1. Biochemical characters of some strains received as Micrococcus freudenreichii and one mucoid strain of Staphylococcus aureus, CCM 2286.

\begin{tabular}{|c|c|c|c|c|c|}
\hline \multirow{2}{*}{ Characters } & \multicolumn{2}{|c|}{ Strains } & \multirow[b]{2}{*}{ NCDO 1222} & \multirow[b]{2}{*}{$\begin{array}{l}\text { DRI \& } \\
\text { NCDO } \\
1223\end{array}$} & \multirow[b]{2}{*}{ CCM 2286} \\
\hline & $\begin{array}{l}\text { ATCC } 407 \\
\text { CCM } 764\end{array}$ & OAC 268 & & & \\
\hline Coagulase & - & - & - & - & + \\
\hline Indol & - & - & - & - & - \\
\hline Voges Proskaver & - & + & + & + & - \\
\hline Citrate & - & - & - & - & - \\
\hline Nitrate & - & + & - & + & + \\
\hline Gelatin & + & - & + & + & + \\
\hline $\mathrm{H}_{2} \mathrm{~S}$-production & - & - & - & - & - \\
\hline Urease & + & + & + & + & - \\
\hline Catalase & + & + & + & + & + \\
\hline Arabinose & - & - & - & - & - \\
\hline Glucose & - & + & + & + & + \\
\hline Gas & - & - & - & - & - \\
\hline Lactose & - & + & + & + & + \\
\hline Maltose & $(+)^{a}$ & - & + & - & + \\
\hline Mannitol & - & + & - & + & + \\
\hline Saccharose & - & + & + & + & + \\
\hline $\begin{array}{l}\text { Skim Milk } \\
\text { Difco }\end{array}$ & $\operatorname{CSL}^{b}$ & CSL & CSL & CSL & CSL \\
\hline $\begin{array}{l}\text { Litmus Milk } \\
\text { Difco }\end{array}$ & RCS & RC & RCS & RCS & $R$ \\
\hline
\end{tabular}

Methods used are mentioned in Bergan et al., 1970a. Strain IFO 3778 is identical to NCIB 2699 which is reported in Bergan et al., 1970a.

a) $(+)=$ Weak reaction

b) $C=$ Coagulated; $S=$ Curds separated with clear whey; $L=$ No production of ropy milk $k_{j} R=$ Litmus reduced. 
However, even disregarding this asset in Guillebeau's description of M. freudenreichii, a mucoid strain of $S$. aureus would seem to be more in accordance with the Guillebeau description than the strains ATCC 407 and CCM 764. This observation relates well to the opinion of Winslow and Winslow (1908) who considered $M$. freudenreichii a mere variant of S. aureus (Albococcus pyogenes in their terminology).

In conclusion, from world wide sources we have been unable to find any micrococcus which complies fully with the few characteristics given in the original description of the species $M$. freudenreichii. Although it seems possible that it could have been a mucoid S. aureus in terms of modern nomenclature, this cannot be decided due to the early date of the original paper.

Due to the fact that the arising problem is not exclusively one of nomenclature referrable to the Judicial Commission, it is to be recommended that the Subcommittee on Taxonomy of Staphylococci and Micrococci of the International Committee on Nomenclature of Bacteria be invited to:

(1) evaluate whether, due to common usage and to avoid confusion, the strain CCM 764 be designated as neotype strain of Micrococcus freudenreichii and this species be defined accordingly (cfr. detailed description by Bergan et al. 1970a),

(2) consider, depending upon the conclusion reached in question (1), whether the Judicial Commission should formulate an Opinion to the effect that the name Micrococcus freudenreichii be placed in the list of nomina rejicienda as a nomen dubium (Provision 3 of the International Code of Nomenclature).

\section{REFERENCES}

Auletta, A.E. and E.R. Kennedy. 1966. Deoxyribonucleic acid base composition if some members of the Micrococcaceae. J. Bact. 92 : 28-34.

Bergan, T., K. B $\phi v r e$ and B. Hovig. 1970a. Reisolation of Micrococcus mucilaginosus Migula 1900. Acta Path. Microbiol. Scand. (in press) and 1970 b. A contribution to the taxonomy of strains within the Micrococcaceae. Fol. Fac. Sci. Univ. Brunensis. (in press)

Boháček, J. and M. Kocur. 1970. DNA base composition and classification of Micrococcaceae. Fol. Fac. Sci. Univ. Brunensis. (in press)

Bergey, D. M., F.C. Harrison, R.S. Breed, B.W. Hammer and F.M. Huntoon. 1923. Bergey's Manual of Determinative Bacteriology. Ist ed. Williams and Wilkins Company, Baltimore.

Breed, R.S., E. G. D. Murray and N.R. Smith. 1957. Bergey's Manual of Determinative Bacteriology. 7th ed. Williams and Wilkins Company. Baltimore.

Editorial Board of the Judicial Commission. 1966. International Code of Nomenclature of Bacteria. Intl. J. Syst. Bacteriol. 16:459-490.

Evans, J.B., W. L. Bradford and C.F. Niven. 1955. Comments concerning the taxonomy of the genera Micrococcus and Staphylococcus. Intl. Bull. Bact. Nomencl. Taxon, 5:61-66.

Guillebeau, A. 1891. Beiträge zur Lehre von den Ursachen der Fadenziehenden Milch. Landwirtschaftliches Jahrbuch der Schweitz. 5: 135- 140 . 
Henriksen, S. D. 1948. Some unusual mucoid organisms. Acta Path. Microbiol. Scand. 25:485-492.

Hucker, G.J. 1924. Studies on the Coccaceae. IV\% The classification of the genus Micrococcus Cohn. New York State Agr. Expt. Sta. Tech. Bull. No. 102 .

Krasil'nikov, N.A. 1949. Diagnostik der Bakterien und Actinomyceten. VEB Gustav Fischer Verlag. Jena 1959. Translation of the Russian edition published in Moscow in 1949.

Migula, W. 1900. System der Bakterien. Gustav Fischer. Jena.

Sandvik, O. 1969. Personal communication.

Thatcher, F.S. and W. Simon. 1957. Some physiological and taxigenic properties of members of the genus Micrococcus in relation to Taxonomy. Intl. Bull. Bact. Nomencl. Taxon. 7:21-36.

Winslow, C.-E.A. and A.R. Winslow. 1908. The systematic relationships of the Coccaceae. John Wiley and Sons. New York. pp. 199 and 204. 